PODOLIANCHUK Olena - Candidate of Economic Sciences, Associate Professor, Head of the Department of Accounting and Taxation in the Fields of the Economy, Vinnytsia National Agrarian University (21008, Vinnytsia, 3 Sonyachna str., e-mail: podolianchuk_1@i.ua).

ПОДОЛЯНЧУК Елена Анатольевна - кандидат экономических наук, доцент, заведующая кафедрой учёта и налогообложения в отраслях экономики, Винницкий национальный аграрный университет (21008, г. Винница, ул. Солнечная, 3, e-mail: podolianchuk_1@i.ua).

УДК: 658.012:338.242

DOI: $10.37128 / 2411-4413-2021-1-9$

\section{CTAH TA НАПРЯМИ УДОСКОНАЛЕННЯ ІНФОРМАЦІЙНОї ПІДТРИМКИ ДІЯЛЬНОСТІ СІЛЬСЬКО- ГОСПОДАРСЬКИХ
ПІДПРИЕМСТВ}

\begin{abstract}
ПРАВДЮК М.В., кандидат економічних наук, доцент кафедри обліку та оподаткування в галузях економіки
\end{abstract} Вінницький національний аграрний університет (м. Вінниця)

\begin{abstract}
У статті уточнено призначення та завдання інформаційної підтримки діяльності сільськогосподарських підприємств, висвітлино ї̈ особливості та досліджено ї̈ стан. Встановлено щз: переважно керівники та спеціалісти усвідомлюють необхідність інформаційної підтримки виробничих та бізнес прочесів, існування безпосереднього зв'язку між обсягами виробництва підприємства та рівнем його діджиталізації. Зазначено, найчастіше підприємства користуються технологіями електронного документообігу, наявність власних сайтів, які майже не використовуються для розміщення реклами, пошуку партнерів та розширення клієнтської бази щзодо збуту сільськогосподарської продукиії. Такий стан інформаційної підтримки діяльності сільськогосподарських підприємств зумовлює: постійне дублювання інформачії та інформаційних потоків; ускладненість швидкого своєчасного знаходження необхідної інформаџії; втрати важливої інформаџї̈, через відсутність автоматизованого системного контролю; нераціональність використання інформаційного масиву, що зумовлює підвищення матеріальних, людських та фінансових витрат; зростання трудовитрат на пошук, обробку, зберігання необхідної інформацї; неможливість проведення автоматизованого аналітичного аналізу та статистичної звітності. Обгрунтовано, щзо для удосконалення інформаційної підтримки в сільськогосподарських підприємствах й підвищення продуктивності пращі персоналу та зручності їх роботи в єдиному інформаційному архітектурному середовищі, доцільно здійснити моделювання й прогнозування бізнес-прочесів із уточненням інформаційних запитів, проаналізувати наявність збоїв $і$ затримок інформачійних потоків, виявити зв'язки та взаємозалежності з іншими інформаційними блоками, розробити сценарії щодо вчасного та достовірного інформаційного забезпечення для здійснення усіх бізнес-прочесів.

Удосконалена інформачійна підтримка в сільськогосподарських підприємствах на засадах єдиного інтегрованого інформаційного архітектурного середовища зі структурним розмежуванням телекомунікаційного доступу дозволить одержати спектр конкурентних переваг.
\end{abstract}


Ключові слова: інформаційна підтримка, діяльність сільськогосподарських підприємств, діджитилізація, інформаційні технології, напрями удосконалення, інформаційне управління.

Рис.: 3. Літ.: 11.

\title{
STATUS AND DIRECTIONS OF IMPROVEMENT OF INFORMATION SUPPORT OF AGRICULTURAL ENTERPRISES
}

\author{
PRA VDIUK Maryna, \\ Candidate of Economic Sciences, Associate Professor, \\ Department of Accounting and Taxation in the Branches of the Economy, \\ Vinnytsia National Agrarian University
} (Vinnytsia)

The article clarifies the purpose and objectives of information support for agricultural enterprises, highlights its features and examines its condition. It is established that: mostly managers and specialists are aware of the need for information support of production and business processes, the existence of a direct link between the volume of production of the enterprise and the level of its digitalization. It is noted that most companies use electronic document management technologies, the availability of their own sites, which are almost never used for advertising, partner search and expanding the customer base for the sale of agricultural products. This state of information support for agricultural enterprises causes: constant duplication of information and information flows; the difficulty of quickly finding the necessary information in a timely manner; loss of important information due to lack of automated system control; irrationality of the use of information, which leads to increased material, human and financial costs; growth of labor costs for search, processing, storage of necessary information; impossibility of conducting automated analytical analysis and static reporting. It is substantiated that for improvement of information support in agricultural enterprises and increase of productivity of personnel and convenience of their work in the uniform information architectural environment, it is expedient to carry out modeling and forecasting of business processes with specification of information inquiries, to analyze existence of failures and delays of information flows. and interdependence with other information blocks, develop scenarios for timely and reliable information support for the implementation of all business processes.

Improved information support in agricultural enterprises on the basis of a single integrated information architectural environment with a structural delimitation of telecommunications access will provide a range of competitive advantages.

Key words: information support, activity of agricultural enterprises, digitization, information technologies, directions of improvement, information management.

Fig.: 3. Ref.: 11.

\section{СОСТОЯНИЕ И НАПРАВЛЕНИЯ СОВЕРШЕНСТВОВАНИЯ ИНФОРМАЦИОННОЙ ПОДДЕРЖКИ ДЕЯТЕЛЬНОСТИ СЕЛЬСКОХОЗЯЙСТВЕННЫХ ПРЕДПРИЯТИЙ}

ПРАВДЮК М.В., кандидат экономических наук, доцент кафедры кафедры учета и налогообложения в отраслях экономики Винницкий национальный аграрный университет (2. Винница) 
B статье конкретизировано назначение и задачи информационной поддержки деятельности сельскохозяйственных предприятий, представлено ее особенности $u$ исследовано ее состояние. Установлено, что: в основном руководители и специалисть осознают необходимость информационной поддержски производственных и бизнес процессов, существование непосредственной связи между объемами производства предприятия и уровнем эго диджитализации. Отмечено, чаще всего предприятия пользуются технологиями электронного документооборота, наличие собственных сайтов, которые свиты не используются для размещения рекламы, поиска партнеров и расширения клиентской базы по сбыту сельскохозяйственной продукиии. Такое положение информационной поддержки деятельности сельскохозяйственных предприятий обуславливает: постоянное дублирование информации и информационных потоков; усложненность быстрого своевременного нахождения необходимой информации потери важной информации, из-за отсутствия автоматизированного системного контроля; нерациональность использования информационного массива, который предопределяет повымение материальных, человеческих и финансовых расходов; рост трудозатрат на поиск, обработку, хранение необходимой информации; невозможность проведения автоматизированного аналитического анализа и статистической отчетности. Обоснованно, что для усовершенствования информационной поддержки в сельскохозяйственных предприятиях и повышения производительности труда персонала и удобства их работы в единственной информационной архитектурной среде, целесообразно осуществить моделирование и прогнозирование бизнес-процессов с уточнением информационных запросов, проанализировать наличие сбоев и задержек информачионных потоков, выявить связки и взаимозависимости с другими информационными блоками, разработать сценарии относительно своевременного и достоверного информационного обеспечения для осуществления всех бизнес-процессов.

Усовершенствованная информационная поддержка в сельскохозяйственных предприятиях на принциипах единственной интегрированной информационной архитектурной среды со структурным разграничением телекоммуникационного доступа позволит получить спектр конкурентных преимуществ.

Ключевые слова: информационная поддержка, деятельность сельскохозяйственных предприятий, диджитилизация, информационные технологии, направления усовершенствования, информационное управление.

Рис. 3. Лит.: 11.

Постановка проблеми. Управління сучасним сільськогосподарським підприємством як складною багаторівневою соціально-економічною ієрархічною системою потребує адекватної інформаційної підтримки щодо його різнопланової діяльності (динаміку бізнес-процесів, комунікаційні ланцюги, їх взаємовплив і взаємозв'язки тощо). На ефективність прийняття управлінських заходів значною мірою впливає своєчасністю, актуальністю об'єктивністю та адекватністю інформаційних потоків, існуючим рівнем діджиталізації на підприємстві та якістю інформаційної архітектури. Інформація, нині вважається $\epsilon$ важливим чинником діяльності сільськогосподарських підприємств, базисом управління бізнес-процесами, швидкого реагування на деформації економічного простору й виклики та запити сьогодення. Рівень інформаційної підтримки $є$ одним із визначальних домінант ефективності діяльності сільськогосподарських підприємств та ухвалення управлінських заходів. 
Важлива роль інформаційної підтримки діяльності сільськогосподарських підприємств зумовлюють цінність і актуальність вище означеної проблеми.

Аналіз останніх досліджень і публікацій. Проблему інформаційної підтримки діяльності сільськогосподарських підприємств розглядало багато учених про що свідчить шерег наукових публікацій, серед яких найбільш значущими вважаємо доробок Г. Калетніка, Н. Єршова, Л. Гуцаленко, О. Боженко, Н. Гудзенко, С. Амонс, О. Шпикуляк, А. Брояка та ін. Проте, нові економічні та соціальні виклики сьогодення, які гостро постали перед сільськогосподарськими підприємствами, пояснюють необхідність дослідження стану інформаційної підтримки їх діяльності та переосмислення наукових підходів і напрямів щодо окреслення шляхів удосконалення інформаційної підтримки з врахуванням сучасних запитів.

Формулювання цілей статті $\epsilon$ виявлення стану й особливостей інформаційної підтримки сучасної діяльності сільськогосподарських підприємств, в умовах нових економічних та соціальних викликів сьогодення та окреслення шляхів удосконалення інформаційної підтримки 3 врахуванням сучасних запитів.

Виклад основного матеріалу дослідження. Як свідчать статистичні дані, сільське господарствао відіграє важливу роль у вітчизняній економіці, оскільки саме воно забезпечило 9\% ВВП 2019 року, 6\% податкових надходжень до бюджету та надали роботу $18 \%$ працездатного населення. Останні десятиліття, значення та вагомість сільського господарства для економічного розвитку України зростало [1]. Звичайно, що високий рівень розвитку сільського господарства багато в чому зумовлений сприятливими природними ресурсами. При цьому, різке коливання кліматичних умов генерує нові виклики для галузі. Водночас, слід акцентувати, що зростання частки сільського господарства у ВВП та експортних надходженнях спостерігалось саме у кризові періоди, що пояснюється відносною стійкістю галузі, тобто в умовах економічної рецесії.

Нині, в період проходження пандемії COVID-19, у багатьох країнах відбувається часткове чи повне призупинення діяльності підприємств. Водночас, спостерігається скорочення платоспроможного попиту на різноманітні групи товарів, що пояснює необхідність зберігання аномально великих запасів деяких груп товарів, реалізацію яких неможливо спрогнозувати, оскільки пандемія COVID-19 негативно вплинула як на виробництво товарів, так і на їх збут через введення обмежень на українську сільськогосподарську продукцію на світових ринках, різку деформацію транспортних ланцюгів, каналів дистрибуції та функціонування експортних ринків, коливання цін, через необхідність дотримання безпечних умов діяльності підприємств. Для сільськогосподарських підприємств України, зважаючи на їх вагому залежність від імпорту (майже 70\% мінеральних добрив у 2018 році імпортувалось, а у 2019 році, обсяги їх імпорту впали на 30\%, частка імпорту насіння ріпаку сягає $82 \%$, насіння соняшника $-79 \%$, насіння цукрового буряка - 54\%, кормових добавок 90\%, а частка імпортованої сільськогосподарської техніки - 67\%) та експортних надходжень [1], такий стан подій вважається додатковим серйозним викликом. 
Окрім того, у конкурентному середовищі помітно змінилися акценти діяльності сільськогосподарських підприємств. Помітними особливостями їх діяльності $\epsilon$ звуження спектру діяльності, централізація фінансового управління, порушення формалізованих каналів та ланцюгів, розширення горизонтальних взаємозв'язків, виробнича діяльність в умовах високих ризиків невизначеності, необхідність підвищення гнучкості й адаптивності діяльності підприємств до конкурентних вимог. Діяльність сільськогосподарських підприємств за викликів сьогодення помітно ускладнилася ще й зрісшою потребою вирішення багатьох соціально-економічних питань, зумовлених пандемією COVID-19, політичними та фінансовими кризовими явищами в країні.

Тобто, ефективна i конкурентоспроможна діяльність сільськогосподарських підприємств в сучасних складних умовах неможлива без проведення якісних змін у системі управління, діджиталізації, впровадження інноваційних механізмів координації, регулювання, контролю, підвищення адаптивності інформаційної підтримки. Тобто, успішна діяльність сільськогосподарських підприємств у сучасному економічному просторі значною мірою визначається адекватністю, гнучкістю та якістю інформаційної підтримки. На важливість інформаційної підтримки діяльності сільськогосподарських підприємств влучно акцентує свою увагу Г.М. Калетнік, він стверджує, що «не одержана вчасно інформація, або ії відсутність можуть стати основою краху не тільки запланованих заходів, а навіть фірми, наслідки цього можуть бути катастрофічні. В процесі аналізу, планування і управління, контролю постійно потрібна інформація» [2, с. 185].

Потрібні нові підходи до інформаційної підтримки діяльності сільськогосподарських підприємств, іiі вища якість, досконаліші методи, технології які забезпечать надійність, конкурентні переваги і ефективність функціонування сільськогосподарських підприємств. «Інформаційна підтримка реалізується в контексті формування інформації (про внутрішнє та зовнішнє середовище) як структурованої сукупності обліково-аналітичних процедур, яка включає у себе певну частину інформаційної бази, методи іiі рекласифікації, перегрупування, узагальнення та обробки, побудованої за принципом найбільшої адаптованості до специфіки діяльності суб'єкта господарювання, релевантності до прийняття рішень та інноваційності. При цьому інтеграція інформації із відповідними елементами проблеми та контекстом конкретного підприємства дозволяє виявити найбільш цінну для осіб, що приймають рішення,інформацію, у тому числі й оцінити альтернативні варіанти вирішення проблеми. інформація об'єднує управління, людей, процеси, технології, які розглядаються як єдина система, а не тільки як окремі елементи» [3, с. 201].

Фактично, для забезпечення успішної діяльності сільськогосподарських підприємств необхідна внутрішня інформація (оперативна, облікова, прогнозна, контрольна), яка об'єктивно ідентифікує виробничо-економічний стан підприємства та його структурних одиниць, та зовнішня інформація, яка знижує невизначеність конкурентного середовища, дає змогу проаналізувати кон'юнктури ринку, знайти партнерів, виявити потреби споживачів та ризики, 
сформувати цінову політику, розробити прогнози і стратегії розвитку тощо. При цьому, за переконанням Г.М. Калетніка «інформація повинна бути:

- високоякісною, вірогідною (мінімальна помилковість);

- повною, точною (відповідність реальним значенням стану справ);

- актуальною (свіжа інформація, не застаріла);

- цінною і корисною (відповідність меті, ситуації на ринку)» [2, с. 184].

Ми повністю підтримуємо позицію Гуцаленко Л.В., яка обгрунтовує, що «ефективна господарська діяльність в умова ринкової економіки та глобальних інтеграційних процесів можлива лише за достатньої поінформованості» і далі доповнює, що «повна, оперативна, достовірна інформація про зовнішні чинники впливу та внутрішнє середовище підприємства дає змогу приймати результативні управлінські рішення й пристосовуватися до нових обставин» [4, с. 83]. Ефективне і конкурентоспроможне функціонування підприємства в таких умовах неможливе без істотних змін у системі управління, використання сучасних механізмів координації і контролю у ній, підвищення якості його інформаційного забезпечення. Ефективність останнього, метою якого $\epsilon$ підготовка і обгрунтування управлінських рішень, значною мірою визначає ефективність управління загалом [5, с. 191].

Інформаційні ресурси можуть відігравати двояку роль в діяльності сільськогосподарських підприємств:

- зі зростанням їх масиву розширюються можливості вдосконалення та модернізації бізнес-процесів, оскільки інформація виступає базисом для діагностики виробничої діяльності, формування оперативних і поточних планів, розробки перспективних стратегій та сценаріїв;

- постійне розширення інформаційного масиву зумовлює проблеми в обробці та управлінні ними, що зменшує оперативність управління виробництвом.

Провідні вчені Вінницького національного аграрного університету слушно стверджують, що «в умовах невизначеного середовища, що постійно змінюється, ефективне функціонування підприємства часто залежить від можливості розробки та впровадження креативних управлінських рішень, що здійснюються на основі інформації. На перший план виходить проблема співвідношення кількості даних та якості інформації, іiі корисність та затребуваність» [6, с. 102]. А, це зумовлює необхідність формування дієвої інформаційної системи, що представляє собою комплекс взаємопов'язаних елементів 3 приймання, накопичення, обробки, збереження, передачі інформації. Передусім, ця інформація включає нормативно-правову й звітну документацію, бухгалтерські та статистичні звіти, плани i прогнози підприємства, контракти, ринкову кон'юнктуру, оперативну інформацію, аналізи тощо. Для результативності інформаційних систем потрібен відповідний організаційний, технічний супровід та комплекс взаємопов'язаних інформаційних ланцюгів, каналів і технологій.

Інформаційна підтримка діяльності сільськогосподарських підприємств це динамічна система взаємопов'язаних інформаційних ланцюгів, каналів i 
технологій, які дозволяють ідентифікувати реальний стан підприємства, виявити чинники впливу та можливості розвитку.

Узагальнюючи і критично оцінюючи існуючі наукові підходи, варто виділити сутнісні характеристики інформаційної підтримки діяльності сільськогосподарських підприємств (рис. 1).

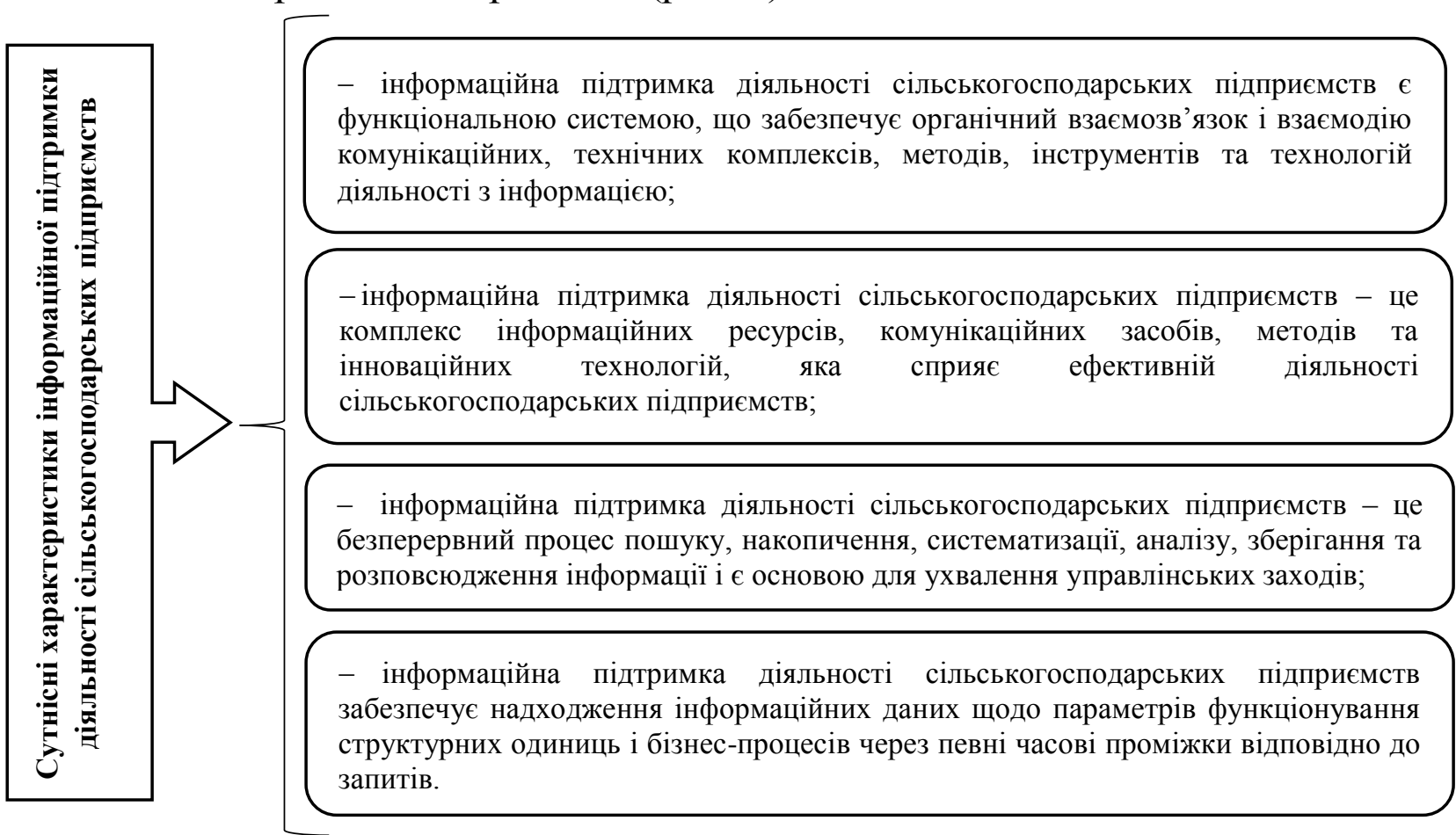

\section{Рис. 1. Сутнісні характеристики інформаційної підтримки діяльності сільськогосподарських підприємств \\ Джерело: сформовано автором}

Інформаційній підтримці діяльності сільськогосподарських підприємств притаманні певні особливості, які необхідно враховувати:

- великий масив внутрішньої та зовнішньої інформації, яка потенційно може впливати на діяльність підприємства та його результати;

- необхідність врахування природних та біологічних факторів;

- забезпечення самоокупності, гнучкості, швидкості та певного рівня самостійності;

- територіальна розпорешеність обєктів діяльності;

- не висока автоматизація бізнес-процесів та логістики.

Основне призначення інформаційної підтримки діяльності сільськогосподарських підприємств полягає у створенні адекватного ефективного інформаційного механізму. Основними завданнями інформаційної підтримки діяльності сільськогосподарських підприємств вважаємо регламентацію обсягів інформаційних даних, якості та часу надходження інформаційних потоків, забезпечення актуальності інформаційного режиму, сегментація і управління інформаційними потоками, нормативно-правовий та програмно-технологічний і комунікаційний супровід засобів, необхідних для діагностики і ухвалення відповідних заходів. «Для прогресивних держав світу 
характерним є перехід від індустріальної економіки до «економіки знань», основою якої є виявлення, створення і максимальне впровадження наукоємних знань на практиці» [7, с. 8].

Призначення та завдання інформаційної підтримки діяльності сільськогосподарських підприємств зумовлюють і вимоги до неї представлено на (рис. 2).

\begin{tabular}{|c|c|}
\hline \multirow{9}{*}{ 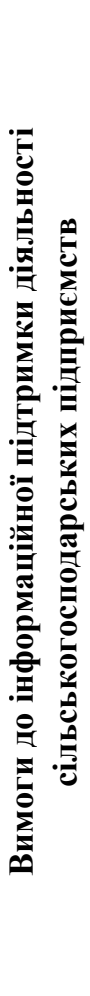 } & $\begin{array}{l}\text { 1. Оперативне надання точної, повної, достовірної, однозначної, стислої, релевантної, } \\
\text { доречної та своєчасної інформації. }\end{array}$ \\
\hline & $\begin{array}{l}\text { 2. Мінімізація витрат на іiі збирання, накопичення, зберігання, пошук, обробку, } \\
\text { кодування, систематизацію і передачу. }\end{array}$ \\
\hline & $\begin{array}{l}\text { 3. Забезпечення кібербезпеки та створення надійних засобів захисту інформаційних } \\
\text { систем від несанкціонованого використання. }\end{array}$ \\
\hline & 4. Надійність інформаційних систем, комунікаційних каналів і технологій. \\
\hline & 5. Формування технічних засобів контролю вхідних та вихідних інформаційних потоків. \\
\hline & 6. Стандартизація документів та забезпечення електронного документообігу. \\
\hline & $\begin{array}{l}\text { 7. Еластичність та сегментація інформаційних потоків (усі користувачі отримують лише } \\
\text { визначену для їх посад інформацію). }\end{array}$ \\
\hline & 8. Оберігати над інформаційних шумів. \\
\hline & 9. Підвищується значення аналітичної та прогнозної інформації. \\
\hline
\end{tabular}

\section{Рис. 2. Вимоги до інформаційної підтримки діяльності сільськогосподарських підприсмств \\ Джерело: сформовано автором}

Головним напрямом перебудови управління та його радикального удосконалення, пристосування до сучасних умов, має стати активне використання новітньої комп'ютерної і телекомунікаційної техніки, формування на ㄲi основі високоефективних інформаційно-управлінських технологій та процесів. Але нові технології, засновані на комп'ютерній техніці, вимагають радикальних змін організаційних структур управління, його регламенту, кадрового потенціалу, системи документації, фіксування i передання інформації. 3 огляду на це, особливого значення набуває впровадження інформаційного управління, що суттєво розширює можливості використання підприємствами інформаційних ресурсів. Розвиток інформаційного управління пов'язаний з організацією системи обробки даних i знань, послідовним їхнім розвитком до рівня інтегрованих автоматизованих систем управління, що охоплюють по вертикалі та горизонталі усі рівні і ланки виробництва та збуту [8, с. 51]. Важливим аспектом розвитку є стратегічне планування як фактор формування конкурентоспроможності підприємств узгоджує потребу підприємств орієнтації у динамічному ринковому середовищі 
та прагненні прогнозувати потенційні зміни, що відбуваються у ньому та безпосередньо впливають на підприємства, а також дозволяє гнучко поєднувати внутрішні та зовнішні аспекти підприємства. Саме від цього залежать успіх та можливості вітчизняних сільськогосподарських підприємств щодо входження на нові світові ринки, доступ до інноваційних технологій, фінансових, матеріальних, інтелектуальних ресурсів, генерування конкурентних переваг [9, c. 17].

Підтримуємо позицію О. Шпикуляка, який стверджує, що «у вітчизняній економіці інформаційна складова бізнесу не вважається пріоритетною через низьку культуру підприємництва» [10, с. 111]. Під час дослідження нами проводилось анонімне анкетування. Загальна кількість респондентів становила 110 осіб, серед яких працівники господарювання різних форм власності Вінницької області. Так, за результатами проведеного опитування керівників та спеціалістів сільськогосподарських підприємств Вінницької області встановлено , що більшість (69 \%) вважає:

- що переважно керівники та спеціалісти усвідомлюють необхідність інформаційної підтримки виробничих та бізнес-процесів;

- існування безпосереднього зв’язку між обсягами виробництва підприємства та рівнем його діджиталізації;

- що найчастіше підприємства користуються технологіями електронного документообігу;

- існування прямого зв’язку між кількістю інфокомунікаційних пристроїв та адміністративного персоналу підприємства;

- відсутність зв'язку між кількістю видів діяльності і бізнес-процесами та інтенсивністю використання інформаційно-комунікаційних технологій;

- наявність власних сайтів, які майже не використовуються для розміщення реклами, пошуку партнерів та розширення клієнтської бази щодо збуту сільськогосподарської продукції;

- слабке використання мережі Інтернет щодо ресурсних онлайн ринків для матеріального забезпечення виробничих процесів;

- наявність застарілого мережевого обладнання, комп’ютерів тощо;

- наявність непрозорих мережевих процесів;

- слабке використання офісного програмного забезпечення;

- низька компетентність працівників та недостатня їх мотивація щодо здійснення цифрових перетворень;

- збільшення використання працівниками різноманітних месенджерів 3 використанням мережі Інтернет;

- переважно мережа Інтернет використовується для: користування електронною поштою, отримання повідомлень від державних структур, здійснення дзвінків за допомогою VoIP-зв’язку, здійснення банківських операцій, проведення відео-конференцій, службових нарад тощо, отримання необхідної інформації про товари та послуги, використання соціальних мереж;

- мало використовуються: послуги хмарних обчислень геолокаційні дані, бухгалтерські прикладні програми, блоги та веб-сайти підприємства 3 
мультимедійним вмістом, сервіси для зберігання файлів хостинг бази даних підприємства;

- мала кількість сільськогосподарських підприємств, що проводили навчання персоналу у сфері інформаційно-комунікаційних технологій (далі IKT);

- зростає вагомість компетентностей ІКТ персоналу.

Для більшості сільськогосподарських підприємств характерною ознакою інформаційної підтримки їх діяльності є різнорідність інформаційних ланцюгів і потоків та не інтегрованість інформаційних систем в єдину інформаційну архітектуру. Тобто, здійснена експертиза системи інформаційної підтримки діяльності сільськогосподарських підприємств засвідчує, що інформаційні потоки і комунікаційні ланцюги використовують різнорідні інформаційні системи, технології, що не формують єдине інформаційне середовище.

Такий стан інформаційної підтримки діяльності сільськогосподарських підприємств зумовлює наступні негативні наслідки (рис. 3).

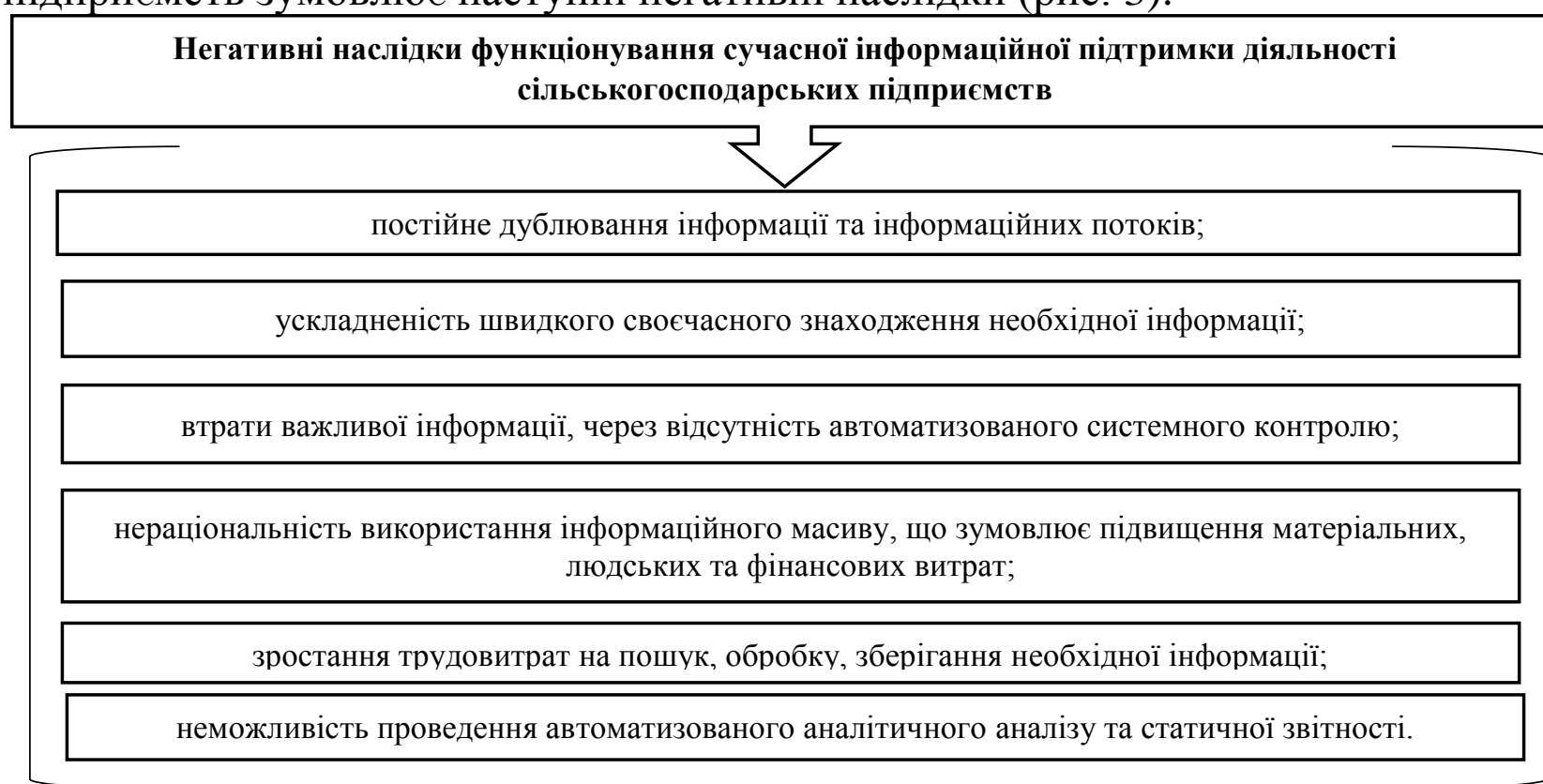

\section{Рис. 3. Негативні наслідки функціонування сучасної інформаційної підтримки діяльності сільськогосподарських підприємств}

Джерело: сформовано автором

Тобто, актуальним є проблема удосконалення інформаційної підтримки в сільськогосподарських підприємствах. Впровадження телекомунікаційних, інтегрованих між собою із елементами штучного інтелекту, засобів обробки інформаційних даних та документації помітно збільшить швидкість пошуку, обробки стрімко зростаючих інформаційних потоків, а потужний економічний ефект відбудеться за рахунок зростання якості ключових виробничих бізнеспроцесів, компетентностей та менеджменту.

Головними засадами організації ефективної інформаційно консультаційної діяльності є: 
- відповідність ії напрямів, методів та заходів цілям аграрної політики держави;

- відповідність результатів інформаційно-консультаційної діяльності завданню росту національного доходу країни та максимізації суспільного ефекту;

- зацікавленість сільгоспвиробників у послугах інформаційноконсультаційних служб та розширенні їхнього переліку;

- зацікавленість самих служб у досягненні зазначених вище результатів та в одержані вигоди не тільки безпосередньо їхніми клієнтами, але й економіки країни загалом;

- зацікавленість регіонів в розвитку служб на їхніх територіях;

- результативність створення та роботи служби з позиції бюджету всіх рівнів (національного, місцевого, районного);

- зацікавленість у співробітництві із науково дослідними установами, проєктними інститутам, дослідними господарствами і станціями, освітніми установами та посередництві між ними і сільськогосподарськими товаровиробниками [10, с. 39].

Для удосконалення інформаційної підтримки в сільськогосподарських підприємствах й підвищення продуктивності праці персоналу та зручності їх роботи в єдиному інформаційному архітектурному середовищі, доцільно здійснити моделювання й прогнозування бізнес-процесів із уточненням інформаційних запитів, проаналізувати наявність збоїв i затримок інформаційних потоків, виявити зв'язки та взаємозалежності 3 іншими інформаційними блоками, розробити сценарії щодо вчасного та достовірного інформаційного забезпечення для здійснення усіх бізнес-процесів.

Удосконалена інформаційна підтримка в сільськогосподарських підприємствах на засадах єдиного інтегрованого інформаційного архітектурного середовища зі структурним розмежуванням телекомунікаційного доступу дозволить одержати наступні переваги:

- прискорити одержання поточної інформації для виконавців бізнеспроцесів;

- оперативно забезпечити всі структурні одиниці необхідною інформацією у необхідні часові проміжки;

- мінімізувати інформаційні шуми та кібер ризики;

- розширити базу інформаційних джерел;

- запобігти дублюванню функцій персоналу та структурних одиниць;

- спростити процес пошуку, накопичення, обробки й зберігання інформації;

- скоротити час на пошук необхідної інформації;

- виконати перерозподіл інфо-комунікаційних функцій працівників;

- сформувати кібер систему інформаційної прозорості;

- використати переваги ефективного доступу до інформації, що знаходиться в електронному архіві; 
- оперативно здійснювати моніторинг та контроль головних індикаторів діяльності підприємства;

- забезпечити об’ єктивність інформації та еластичність інформаційного масиву.

Висновки. У статті здійснено дослідження стану й особливостей інформаційної підтримки сучасної діяльності сільськогосподарських підприємств, в умовах нових економічних та соціальних викликів сьогодення та окреслення шляхів удосконалення інформаційної підтримки 3 врахуванням сучасних запитів. Обгрунтовано, що основне призначення інформаційної підтримки діяльності сільськогосподарських підприємств полягає у створенні адекватного ефективного інформаційного механізму, а ключовими завданнями інформаційної підтримки діяльності сільськогосподарських підприємств слід вважати регламентацію обсягів інформаційних даних, якості та часу надходження інформаційних потоків, забезпечення актуальності інформаційного режиму, сегментація і управління інформаційними потоками, нормативно-правовий та програмно-технологічний і комунікаційний супровід засобів, необхідних для діагностики і ухвалення відповідних заходів. Ефективність інформаційної підтримки в сільськогосподарських підприємствах часто визначається рівнем автоматизації, комп’ютеризації та інтелектуалізації інформаційних систем, які формуються на базі новітніх технологій і телекомунікаційних засобів.

Для більшості сільськогосподарських підприємств характерною ознакою інформаційної підтримки їх діяльності є різнорідність інформаційних ланцюгів і потоків та не інтегрованість інформаційних систем в єдину інформаційну архітектуру. Тобто, здійснена експертиза системи інформаційної підтримки діяльності сільськогосподарських підприємств засвідчує, що інформаційні та документаційні потоки і комунікаційні ланцюги використовують різнорідні інформаційні системи, технології, що не формують єдине інформаційне середовище. Для удосконалення інформаційної підтримки в сільськогосподарських підприємствах й підвищення продуктивності праці персоналу та зручності їх роботи в єдиному інформаційному архітектурному середовищі, доцільно здійснити моделювання й прогнозування бізнес-процесів iз уточненням інформаційних запитів, проаналізувати наявність збоїв i затримок інформаційних потоків, виявити зв'язки та взаємозалежності 3 іншими інформаційними блоками, розробити сценарії щодо вчасного та достовірного інформаційного забезпечення для здійснення усіх бізнес-процесів.

\section{Список використаних джерел}

1. Офіційний сайт Державної служби статистики України. URL: http://www.ukrstat.gov.ua (дата звернення: 31.08.2020).

2. Калетнік Г.М., Ціхановська В.М., Ціхановська О.М. Менеджмент та маркетинг: навчальний посібник. Київ: «Хай-Тек Прес». 2011. 580 с.

3. Сршова Н.Ю. Концептуальні основи стратегічного управлінського обліку. Проблеми економіки. 2017. № 1. С.195-202. 
4. Гуцаленко Л.В., Довгаль Е.О. Обліково-інформаційна система забезпечення управління сільськогосподарським підприємством. Економіка. Фінанси. Менеджмент: актуальні питання науки і практики. 2016. № 8. С.8292.

5. Боженко О.M. Інформаційне забезпечення управління потенціалом підприємства. Наукові записки Украӥнської академії друкарства. 2016. № 2. C. 189-197. Режим доступу: http://nbuv.gov.ua/UJRN/Nz_2016_2_2 (дата звернення: 31.08.2020).

6. Гудзенко Н.М., Коваль Н.І., Плахтій Т.Ф. Вплив інформаційних потреб користувачів на структуру та наповнення фінансової звітності. Економіка.Фінанси.Менеджмент: актуальні питання науки і практики. 2018. № 5. C.102-113.

7. Калетнік Г.М., Гунько І.В. Інноваційні платформи організації науководискусійних молодіжних майданчиків у контексті євроінтеграційного розвитку аграрної економіки. Економіка. Фінанси. Менеджмент: актуальні питання науки і практики. 2017. № 4. С.7-18.

8. Щербак А.М. Оцінювання інформаційних процесів управління промисловим підприємством: дис. канд. екон. наук: 08.00.04. Харків, 2019. $249 \mathrm{c}$.

9. Амонс С.А., Красняк О.П. Роль стратегічного планування як фактору формування конкурентноспроможності аграрного підприємства. Colloquiumjournal. 2020. № 34 (86). С. 12-17.

10. Шпикуляк О.Г. Інституції аграрного ринку: монографія. Київ: ННЦ «Інститут аграрної економіки». 2009. 480 с.

11. Брояка А.А. Концептуальні засади організації ефективного інформаційно-консультаційного забезпечення сільського господарства. Агросвіт 2016. № 21. С. 36-42.

\section{References}

1. Ofitsiinyi sait Derzhavnoi sluzhby statystyky Ukrainy [Official site of the State Statistics Service of Ukraine]. ukrstat.gov.ua. Retrieved from: http://www.ukrstat.gov.ua/ [in Ukrainian].

2. Kaletnik, G.M., Tsikhanovska, V.M., \& Tsikhanovska, O.M. (2011). Menedzhment ta marketynh [Management and marketing]. Kyiv: «Khai-Tek Pres» [in Ukrainian].

3. Yershova, N.Yu. (2017). Kontseptualni osnovy stratehichnoho upravlinskoho obliku [Conceptual bases of strategic management accounting.] Problemy ekonomiky - Problems of the economy, 1, 195-202 [in Ukrainian].

4. Hutsalenko, L.V., Dovhal, E.O. (2016). Oblikovo-informatsiina systema zabezpechennia upravlinnia silskohospodarskym pidpryiemstvom [Accounting and information system for agricultural enterprise management.] Ekonomika. Finansy. Menedzhment: aktualni pytannia nauky $i$ praktyky - Economy. Finances. Management: current issues of science and practice, 8, 82-92 [in Ukrainian].

5. Bozhenko, O.M. (2016). Informatsiine zabezpechennia upravlinnia potentsialom pidpryiemstva [Information support of enterprise potential 
management.] Naukovi zapysky Ukrainskoi akademii drukarstva - Scientific notes of the Ukrainian Academy of Printing, 2, 189-197 Retrieved from: http://nbuv.gov.ua/UJRN/Nz_2016_2_2 [in Ukrainian].

6. Hudzenko, N.M., Koval, N.I., \& Plakhtii, T.F. (2018). Vplyv informatsiinykh potreb korystuvachiv na strukturu ta napovnennia finansovoi zvitnosti [The impact of information needs of users on the structure and content of financial statements]. Ekonomika.Finansy. Menedzhment:aktualni pytannia nauky $i$ praktyky - Economics. Finance. Management: current issues of science and practice, 5, 102-113 [in Ukrainian].

7. Kaletnik, G.M., \& Hunko, I.V. (2017). Innovatsiini platformy orhanizatsii naukovo-dyskusiinykh molodizhnykh maidanchykiv u konteksti yevro intehratsiinoho rozvytku ahrarnoi ekonomiky [Innovative platforms for the organization of research and discussion youth platforms in the context of European integration development of the agricultural economy]. Ekonomika. Finansy. Menedzhment: aktualni pytannia nauky $i$ praktyky - Economics. Finance. Management: current issues of science and practice, 4, 7-18 [in Ukrainian].

8. Shcherbak, A.M. (2019). Otsiniuvannia informatsiinykh protsesiv upravlinnia promyslovym pidpryiemstvom [Evaluation of information processes of industrial enterprise management]. Candidate's thesis. Kharkiv: Semyon Kuznets Kharkiv National University of Economics [in Ukrainian].

9. Amons, S.A., \& Krasniak, O.P. (2020). Rol stratehichnoho planuvannia yak faktoru formuvannia konkurentnospromozhnosti ahrarnoho pidpryiemstva [The role of strategic planning as a factor in shaping the competitiveness of agricultural enterprises]. Colloquium-journal - Colloquium-journal, 34 (86), 12-17 [in Ukrainian].

10. Shpykuliak, O.H. (2009). Instytutsii ahrarnoho rynku [Agricultural market institutions]. Kyiv: NSC «Institute of Agrarian Economics» [in Ukrainian].

11. Broiaka, A.A. (2016). Kontseptualni zasady orhanizatsii efektyvnoho informatsiino-konsultatsiinoho zabezpechennia silskoho hospodarstva [Conceptual principles of organization of effective information and consulting support of agriculture]. Ahrosvit - Agrosvit, 21, 36-42 [in Ukrainian].

\section{Інформація про автора}

ПРАВДЮК Марина Володимирівна - кандидат економічних наук, доцент кафедри обліку та оподаткування в галузях економіки, Вінницький національний аграрний університет (21008, м. Вінниця, вул. Сонячна, 3, e-mail: a.pravd4449@gmail.com).

PRAVDIUK Maryna - Candidate of Economic Sciences, Associate Professor, Vinnytsia National Agrarian University (21008, Vinnytsia, 3 Soniachna str., e-mail: a.pravd4449@gmail.com).

ПРАВДЮК Марина Владимировна - кандидат экономических наук, доцент кафедры учета и налогообложения в отраслях экономики, Винницкий национальный аграрный университет 21008, м. Винница, ул. Солнечная, 3, e-mail: a.pravd4449@gmail.com). 